\title{
3D models related to the publication: Djebelemur, a tiny pre-tooth-combed primate from the Eocene of Tunisia: a glimpse into the origin of crown strepsirhines
}

\author{
Marivaux Laurent ${ }^{1 *}$, Lebrun Renaud ${ }^{1}$, Tabuce Rodolphe ${ }^{1}$ \\ ${ }^{1}$ Institut des Sciences de l'Évolution de Montpellier (ISE-M, UMR 5554, CNRS/UM/IRD/EPHE), c.C. 064, Université de Montpellier, place \\ Eugène Bataillon, 34095 Montpellier Cedex 05, France \\ *Corresponding author: Laurent.Marivaux@UMontpellier.fr
}

\section{Abstract}

This contribution contains the 3D models of the fossil remains (maxilla, dentary, and talus) attributed to Djebelemur martinezi, a ca. $50 \mathrm{Ma}$ primate from Tunisia (Djebel Chambi), described and figured in the following publication: Marivaux et al. (2013), Djebelemur, a tiny pre-tooth-combed primate from the Eocene of Tunisia: a glimpse into the origin of crown strepsirhines. PLoS ONE. https://doi.org/10.1371/journal.pone.0080778

Keywords: Africa, Djebelemuridae, Paleogene, Primates, Strepsirhini

Submitted:2018-09-21, published online:2018-10-05. https://doi.org/10.18563/journal.m3.77

\section{INTRODUCTION}

We present here the 3D digital models of several fossil specimens (Figs 1 and 2; Table 1) documenting a small-bodied primate: Djebelemur martinezi Hartenberger and Marandat, 1992. The fossils were discovered in the western part of central Tunisia (Kassérine region, Djebel Chambi; 2008 and 2009 field campaigns) from lacustrine deposits (CBI-1) dating from the late Early Eocene (Hartenberger and Marandat, 1992; Hartenberger et al., 1997, 2001; Tabuce et al., 2011; Marivaux et al., 2015). They were recovered after several rounds of acid processing and wet screening of the indurated calcareous matrix. In Marivaux et al. (2013), the new published material documenting Djebelemur consisted of a facial fragment (left maxilla) preserving P3-M3 and alveoli for P2 and C (CBI-1-544; Fig. 1A-B), a fragmentary lower jaw preserving $\mathrm{m} 1-3, \mathrm{p} 3$ and alveoli for p4, p2 and canine (CBI-1-565; Fig. 1D), few isolated teeth among which a right $\mathrm{p} 4$ (CBI-1-577; Fig. 1E-F), a left p2 (CBI-1-587; Fig. 1E-F), a left lower canine (CBI-1-580; Fig. 1E-F) and a left P4 (CBI-1-567; Fig. 1C), and finally an isolated talus (CBI-1-545; Fig. 2AF). Cranial, dental and postcranial remains indicate that this diminutive primate was likely nocturnal, predatory (primarily insectivorous), and engaged in a form of generalized arboreal quadrupedalism with frequent horizontal leaping (Marivaux et al., 2013). These fossils provide additional morphological evidence for demonstrating the "advanced" stem strepsirhine status of Djebelemur, which is clearly more closely related to tooth-combed primates (crown Strepsirhini sensu stricto; i.e., lorises, galagos, and lemurs) than any adapiforms (Strepsirhini sensu lato). Djebelemur did not have an anterior lower dentition as specialized as that characterizing most crown strepsirhines (i.e., tooth-comb), but it clearly exhibited a transformed antemolar pattern representing an early stage to-

\section{Model IDs \\ CBI-1-544 \\ CBI-1-567 \\ CBI-1-565-577- \\ $587-580$ \\ CBI-1-545

\author{
Description \\ Left maxilla preserving P3-M3 \\ and alveoli for $\mathrm{P} 2$ and $\mathrm{C} 1$ \\ CBI-1-567, left upper P4 \\ Composite mandible \\ reconstruction \\ Right Talus
}

Table 1. List of specimens and associated models of Djebelemur martinezi. All fossils referenced and figured in this paper are housed in the paleontological collections of the museum of the "Office National des Mines" (MONM) of Tunis, Tunisia.

ward a crown strepsirhine-like adaptation ("pre-tooth-comb"). These new fossil data suggest that the differentiation of the tooth-comb must postdate the djebelemurid divergence, a view which hence constrains the timing of crown strepsirhine origins to the Middle Eocene, and then precludes the existence of unrecorded lineage extinctions of tooth-combed primates during the earliest Tertiary.

\section{METHODS}

AVIZO 7.1 (Visualization Sciences Group) software was used for visualization, segmentation and $3 \mathrm{D}$ rendering. The teeth were prepared within a "labelfield" module of AVIZO, using the segmentation threshold selection tool. The 3D models are provided in .ply format, and then can be opened with a wide range of freeware. The .ply files were generated with MorphoDig, an open-source 3D freeware (Lebrun, 2018). 


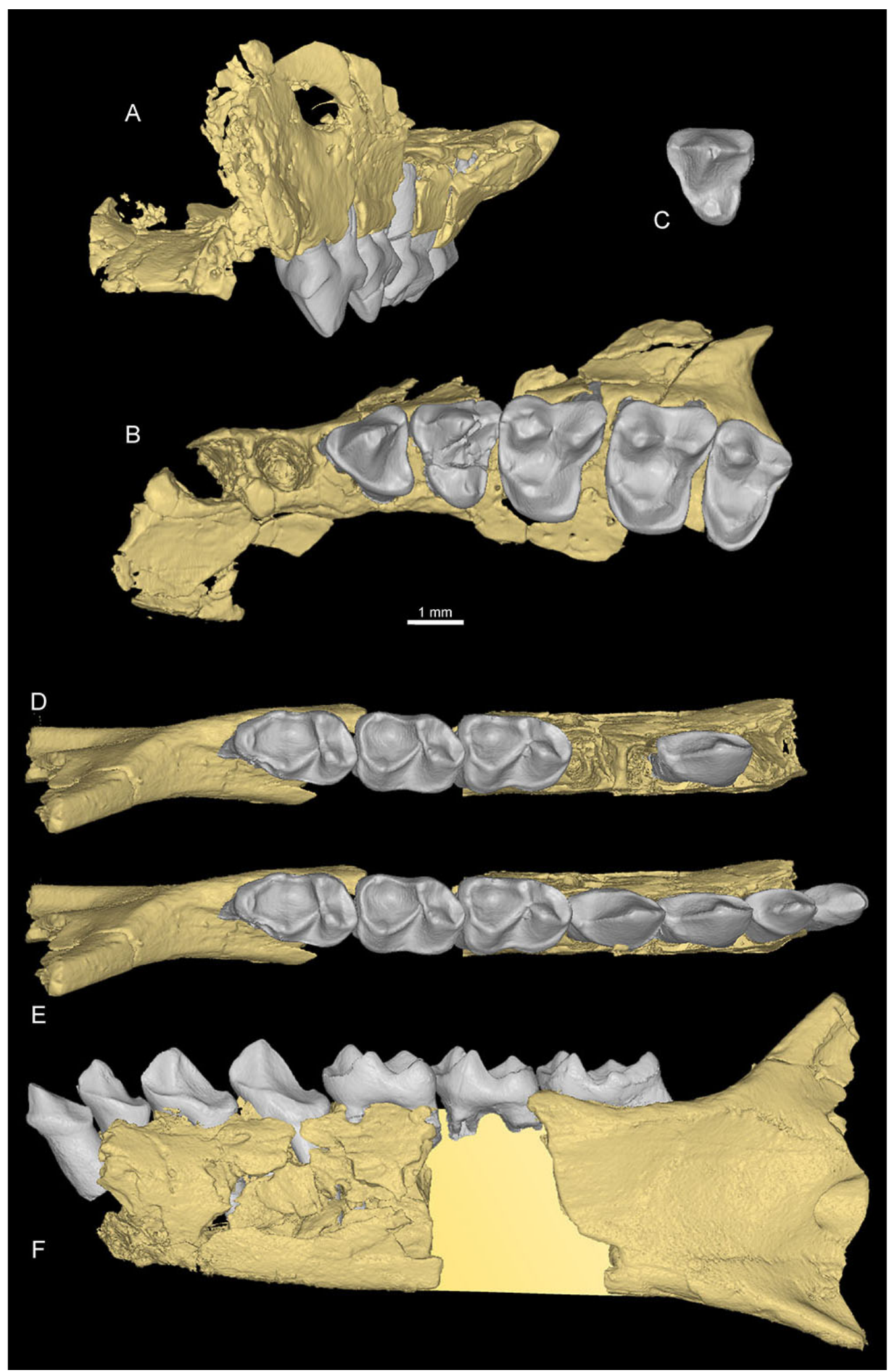

Figure 1. Fossil specimens of Djebelemur martinezi from the late Early Eocene of Djebel Chambi locus $n^{\circ} 1(\mathrm{CBI}-1)$, western part of central Tunisia. A-B) CBI-1-544, left maxilla preserving P3-M3 and alveoli for P2 and C1, in frontal (A) and palatal (B) views. C) CBI-1-567, left P4 in occlusal view. D) CBI-1-565, a damaged right mandible, which consists of three isolated pieces found together and reassembled here: the anterior part of the dentary bears the $\mathrm{p} 3$ and $\mathrm{m} 1$, and alveoli for $\mathrm{p} 4, \mathrm{p} 2$ and $\mathrm{c}$, while the posterior part preserves $\mathrm{m} 3$ and a portion of the ascending ramus; the $\mathrm{m} 2$ was found isolated but in the same small calcareous block treated by acid processing. E-F) composite lower toothrow including the fragmentary CBI-1-565 right mandible, the CBI-1-580 left lower canine (reversed), the CBI-1-587 left p2 (reversed) and the CBI-1-577 right $\mathrm{p} 4$, in occlusal (E) and lingual (F) views. 


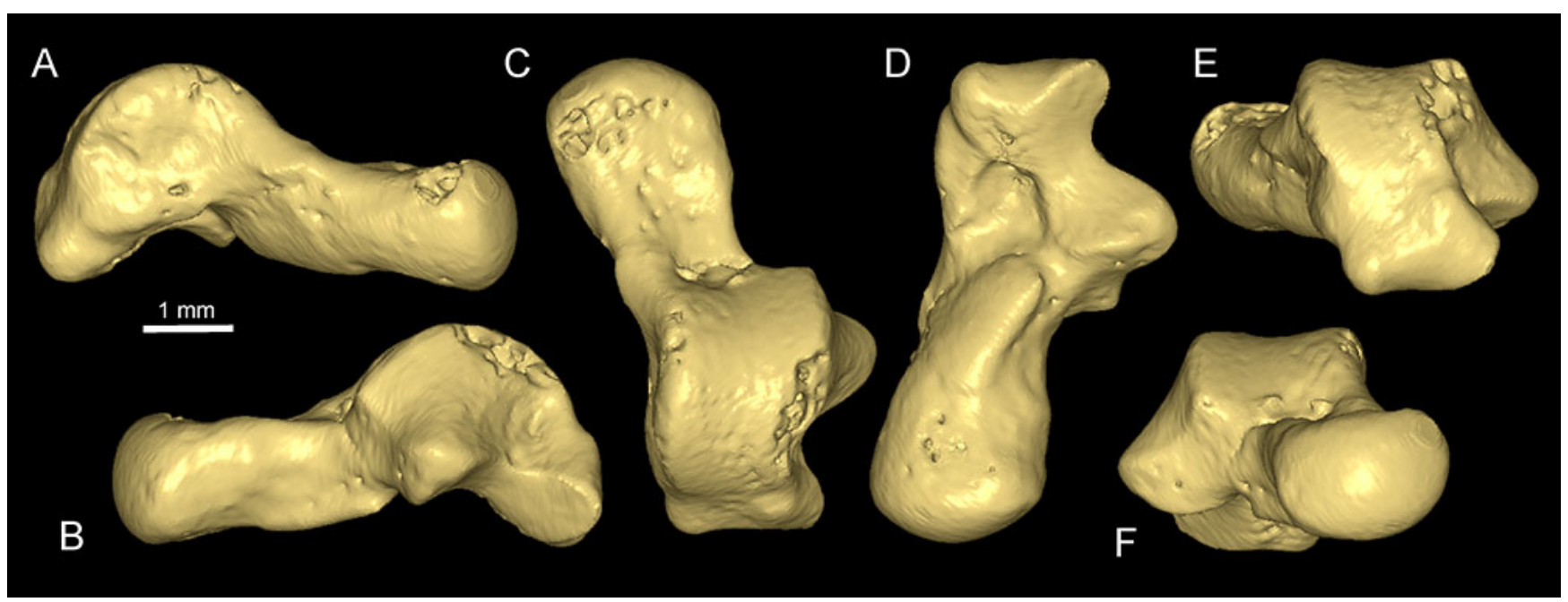

Figure 2. Ankle bone (or talus) of primate from the Djebel Chambi CBI-1 locality, attributed to Djebelemur martinezi. A-F) CBI-1-545, right talus in medial (A), lateral (B), dorsal (C), plantar (D), proximal (E) and distal (F) views.

\section{ACKNOWLEDGEMENTS}

3D data presented in this work were produced through the technical facilities of the Montpellier RIO Imaging (MRI) platform and of the LabEx CeMEB. We are highly indebted to Anne-Lise Charruault (ISE-M) for her substantial contribution in the chemical extraction and preparation in our lab of the fossil specimens from Chambi CBI-1. Many thanks to all the team members having contributed on the field to the discovery of these fossils (Anne-Lise Charruault, El Mabrouk Essid, Suzanne Jiquel, Bernard Marandat, Wissem Marzougui, Gilles Merzeraud, Faouzi M'Nasri, Anusha Ramdarshan, Anthony Ravel, and Monique Vianey-Liaud). This work (paleontological fieldwork and laboratory post-field analyses) was financially supported by the French ANR-ERC PALASIAFRICA (ANR-08-JCJC-0017).

\section{BIBLIOGRAPHY}

Hartenberger, J.-L., Crochet, J.-Y., Martinez, C., Feist, M., Godinot, M., Mannai Tayech, B., Marandat, B., Sigé, B., 1997. Le gisement de mammifères de Chambi (Éocène, Tunisie centrale) dans son contexte géologique. Apport à la connaissance de l'évolution des mammifères en Afrique. In: Aguilar, J.-P., Legendre, S., Michaux, J. (Eds), Actes du Congrès BiochroM'97. Mémoires des Travaux de l'E.P.H.E., Montpellier, pp. 263-274.

Hartenberger, J.-L., Crochet, J.-Y., Martinez, C., Marandat, B., Sigé, B., 2001. The Eocene mammalian fauna of Chambi (Tunisia) in its geological context. In: Gunnell, G. F. (Ed.), Eocene Biodiversity: Unusual Occurrences and Rarely Sampled Habitats. Kluwer Academic/Plenum, New York, pp. 237-250. https://doi.org/10.1007/978-1-4615-1271-4_9

Hartenberger, J.-L., Marandat, B., 1992. A new genus and species of an early Eocene primate from North Africa. Human Evolution 7(1), 9-16. https://doi.org/10.1007/BF024374 74
Lebrun, R., 2018. MorphoDig, an open-source 3D freeware dedicated to biology. 5th International Paleontological Congress (IPC5) - The Fossil Week, July 9-13th, 2018 (Paris, France). Abstract volume, 399.

Marivaux, L., Ramdarshan, A., Essid, E. M., Marzougui, W., Khayati Ammar, H., Lebrun, R., Marandat, B., Merzeraud, G., Tabuce, R., Vianey-Liaud, M., 2013. Djebelemur, a tiny pre-tooth-combed primate from the Eocene of Tunisia: a glimpse into the origin of crown strepsirhines. PLoS ONE 8(12-e80778), 1-21. https://doi.org/10.1371/journal.pone. 0080778

Marivaux, L., Essid, E. M., Marzougui, W., Khayati Ammar, H., Merzeraud, G., Tabuce, R., Vianey-Liaud, M., 2015. The early evolutionary history of anomaluroid rodents in Africa: new dental remains of a zegdoumyid (Zegdoumyidae, Anomaluroidea) from the Eocene of Tunisia. Zoologica Scripta 44(2), 117-134. https://doi.org/10.1111/zsc.12095

Tabuce, R., Charruault, A.-L., Adaci, M., Bensalah, M., Ben Haj Ali, M., Essid, E. M., Marivaux, L., Vianey-Liaud, M., Mahboubi, M., 2011. The early Eocene radiation of Hyracoidea (Mammalia, Afrotheria): new fieldwork evidence from northwestern Africa. In: Lehmann, T., Schaal, S. F. K. (Eds), 22nd International Senckenberg - The World at the Time of Messel: Puzzles in Palaeobiology, Palaeoenvironment and the History of Early Primates. Senckenberg Gesellschaft für Naturforschung, Frankfurt. pp. 161-162. 